\title{
The separator-divided soluble lead flow battery
}

\author{
M. Krishna ${ }^{1} \cdot$ R. G. A. Wills ${ }^{1}$ (D) A. A. Shah ${ }^{2} \cdot$ D. Hall ${ }^{3} \cdot$ J. Collins $^{3}$
}

Received: 22 March 2018 / Accepted: 1 July 2018 / Published online: 7 July 2018

(c) The Author(s) 2018

\begin{abstract}
The soluble lead flow battery (SLFB) is conventionally configured with an undivided cell chamber. This is possible, unlike other flow batteries, because both electrode active materials are electroplated as solids from a common species, $\mathrm{Pb}^{2+}$, on the electrode surfaces during charging. Physically separating the active materials has the advantage that a single electrolyte and pump circuit can be used; however, failure mechanisms such as electrical shorting may be observed. In addition, a common electrolyte requires that any electrolyte additives are compatible with both half-cell reactions. This paper introduces two new configurations; semi- and fully divided for the SLFB. Cationic, anionic, and microporous separators are assessed for ionic conductivity in SLFB electrolytes, showing that their incorporation adds as little as a $20 \mathrm{mV}$ to the cell voltage. Voltammetry shows the effect of additives on the equilibrium potential and stripping overpotential of $\mathrm{PbO}_{2}$. It is then demonstrated that the incorporation of a separator into the SLFB can reduce failure due to electrical shorting and permit electrode-specific additives to be used. A unit flow cell with electrode area of $100 \mathrm{~cm}^{2}$ is shown to operate for over $300 \mathrm{Ah}$ in the semi-divided configuration, more than doubling the previously reported cycle life for cells of similar size.
\end{abstract}

\section{Graphical Abstract}

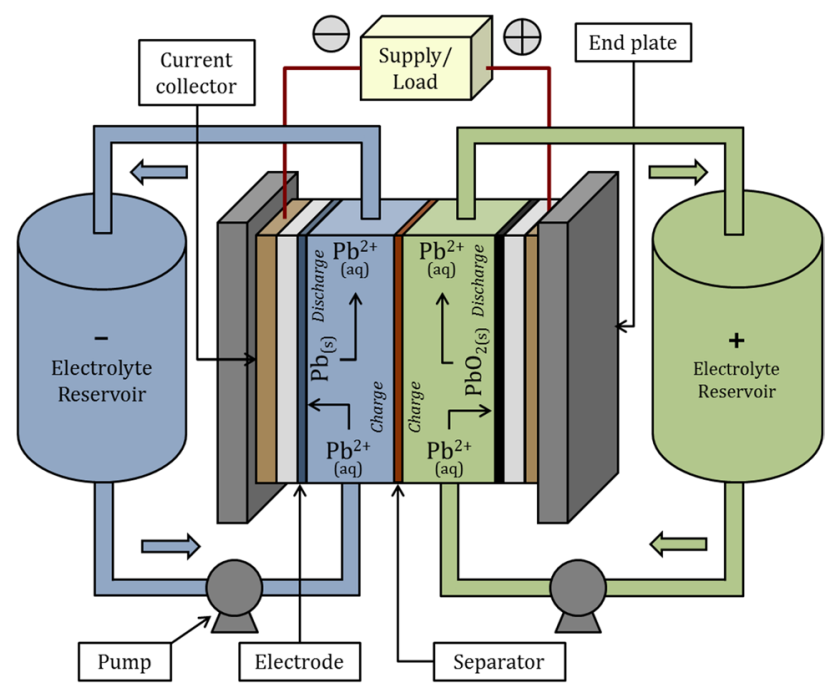

Keywords Soluble lead $\cdot$ Methanesulfonic acid $\cdot$ Flow battery $\cdot$ SLFB

\section{Introduction}

R. G. A. Wills

rgaw@soton.ac.uk

Extended author information available on the last page of the article
The soluble lead flow battery (SLFB) is a hybrid flow battery that stores energy in the form of solid lead and lead dioxide electrodeposits at the negative and positive electrodes, respectively. At zero state of charge (SoC), the maximum 
concentration of $\mathrm{Pb}^{2+}$ ions is dissolved in the aqueous methanesulfonic acid (MSA), $\mathrm{CH}_{3} \mathrm{SO}_{3} \mathrm{H}$, electrolyte solution. At $100 \% \mathrm{SoC}$, the minimum concentration of solvated $\mathrm{Pb}^{2+}$ ions is reached. The minimum concentration of solvated $\mathrm{Pb}^{2+}$ ions is determined by mass transport limits for the $\mathrm{Pb}^{2+}$ ions to the reaction surface of the electrodes [1]. The cell equations are as follows, where the forward reaction represents charging and the reverse reaction discharging:

$$
\begin{aligned}
& \mathrm{Pb}_{(\mathrm{aq})}^{2+}+2 \mathrm{e}^{-} \leftrightharpoons \mathrm{Pb}_{(\mathrm{s})} \\
& E_{-\mathrm{ve}}^{\mathrm{o}}=-0.130 \mathrm{~V} \text { vs. SHE } \\
& \mathrm{Pb}_{(\mathrm{aq})}^{2+}+2 \mathrm{H}_{2} \mathrm{O}_{(\mathrm{l})} \leftrightharpoons \mathrm{PbO}_{2(\mathrm{~s})}+4 \mathrm{H}_{(\mathrm{aq})}^{+}+2 \mathrm{e}^{-} \\
& E_{+\mathrm{ve}}^{\mathrm{o}}=+1.468 \mathrm{~V} \text { vs. SHE } \\
& 2 \mathrm{~Pb}_{(\mathrm{aq})}^{2+}+2 \mathrm{H}_{2} \mathrm{O}_{(\mathrm{l})} \leftrightharpoons \mathrm{Pb}_{(\mathrm{s})}+\mathrm{PbO}_{2(\mathrm{~s})}+4 \mathrm{H}_{(\mathrm{aq})}^{+} \\
& E_{\text {cell }}^{\mathrm{o}}=+1.598 \mathrm{~V} .
\end{aligned}
$$

The standard potential difference between these reactions is close to 1.6 V. Papers exploring the fundamental properties of the electrolyte [1-5], electrode reactions and materials [6], proof of concept (electrode area $<10 \mathrm{~cm}^{2}$ ), unit cell operation [6,7], and system have been published, alongside charge/ discharge cycling using cells at an engineering scale (electrode area $=100 \mathrm{~cm}^{2}$ ) [8-10]. All current literature describes flow batteries with cell configurations that do not require a separator, which, whilst simplifying the cell design and lowering its cost, also limits its cycle life. The growth of lead dendrites, lead dioxide creep, and sloughing of material from each electrode deposit can result in electrical contact, shorting the cell, while insoluble lead oxide sludge can form at the positive electrode [8]. A detailed review of the SLFB has recently been published [11]. Dividing the cell allows for tailoring of the half cells individually [12]. This paper describes a method for mitigating against cell failure mechanisms using a separator to divide the cell. Dividing the soluble lead flow cell with a separator allows the use of electrode-specific additives (to control the growth, morphology, and conductivity of deposits) whilst also providing a physical barrier to abnormal deposit growth and sedimentation causing electrical shorts. Two novel cell configurations (semi-divided and fully divided) are introduced along with the previously described undivided system. The work demonstrates, for the first time, that SLFB has performance advantages when it is operated in a divided configuration.

\section{Experimental}

All chemical reagents were purchased from SigmaAldrich. Solutions consisted of lead(II) methanesulfonate solution, $\mathrm{Pb}\left(\mathrm{CH}_{3} \mathrm{SO}_{3}\right)_{2}, 50 \mathrm{wt} \%$ in water (\#462667); methanesulfonic acid (MSA), $\mathrm{CH}_{3} \mathrm{SO}_{3} \mathrm{H},>99.5 \mathrm{wt} \%$ in water (\#471356); deionised water from a Purite Ondeo 15 purifier. Certain tests also made use of the following additives: sodium lignosulfonate $\left(M_{\mathrm{w}}=8000, \# 370975\right)$; bismuth(II) oxide (\#202827); tin(II) methanesulfonate solution, $\mathrm{Sn}\left(\mathrm{CH}_{3} \mathrm{SO}_{3}\right)_{2}, 50 \mathrm{wt} \%$ in water (\#462675); polyvinylpyrrolidone (PVP, $M_{\mathrm{w}}=40,000$, \#PVP40); gadolinium(III) oxide (\#278513); ethylenediaminetetraacetic acid disodium salt dihydrate (EDTA) (\#E4884); zinc(II) oxide (\#251607).

A four-compartment glass cell was employed to deduce the potential drop across several separators. This consisted of two identical halves clamped together with the separator compressed in between, exposing an area of $1.16 \mathrm{~cm}^{2}$. Each half contained one chamber for a reference electrode and one working electrode chamber. A PSU provided a constant current across the separator via two carbon/ polyvinyl ester working electrodes. Two Luggin capillaries placed on either side of the separator, approximately $2 \mathrm{~mm}$ from the separator surface and each leading to a $\mathrm{Hg} /$ $\mathrm{HgO}$ reference electrode, recorded the potential difference between the two Luggin capillary points, i.e., the potential drop across the membrane observed when passing a current between the two working electrodes. The separators were tested using four different solutions simulating different levels of $\mathrm{Pb}^{2+}$ utilisation (the ratio of $\mathrm{Pb}$ deposited at the electrodes to $\mathrm{Pb}^{2+}$ initially in solution), based on an initial electrolyte composition of $0.7 \mathrm{~mol} \mathrm{dm}^{-3}$ $\mathrm{Pb}\left(\mathrm{CH}_{3} \mathrm{SO}_{3}\right)_{2}$ and $1.0 \mathrm{~mol} \mathrm{dm}{ }^{-3} \mathrm{CH}_{3} \mathrm{SO}_{3} \mathrm{H}$. The merits of this electrolyte composition have previously been published [5]:

(a) 0\% utilisation: $0.7 \mathrm{~mol} \mathrm{dm}^{-3} \mathrm{~Pb}\left(\mathrm{CH}_{3} \mathrm{SO}_{3}\right)_{2}$ and $1.0 \mathrm{~mol} \mathrm{dm}^{-3} \mathrm{CH}_{3} \mathrm{SO}_{3} \mathrm{H}$

(b) $33 \%$ utilisation: $0.46 \mathrm{~mol} \mathrm{dm}^{-3} \mathrm{~Pb}\left(\mathrm{CH}_{3} \mathrm{SO}_{3}\right)_{2}$ and $1.48 \mathrm{~mol} \mathrm{dm}^{-3} \mathrm{CH}_{3} \mathrm{SO}_{3} \mathrm{H}$

(c) $66 \%$ utilisation: $0.23 \mathrm{~mol} \mathrm{dm}^{-3} \mathrm{~Pb}\left(\mathrm{CH}_{3} \mathrm{SO}_{3}\right)_{2}$ and $1.94 \mathrm{~mol} \mathrm{dm}^{-3} \mathrm{CH}_{3} \mathrm{SO}_{3} \mathrm{H}$

(d) $100 \%$ utilisation: 0 mol dm$~_{-3} \mathrm{~Pb}\left(\mathrm{CH}_{3} \mathrm{SO}_{3}\right)_{2}$ and $2.4 \mathrm{~mol} \mathrm{dm}^{-3} \mathrm{CH}_{3} \mathrm{SO}_{3} \mathrm{H}$

To evaluate the resistance of the separators, each material was soaked in the test solution for a minimum of $3 \mathrm{~h}$ to allow thorough wetting, and the glass cell was filled with the same solution for the test. In each test, the supplied current was increased from 0 to 100 to $200 \mathrm{~mA}(0,86$ and $172 \mathrm{~mA} \mathrm{~cm}^{-2}$ separator area, respectively). The potential 
drop across the separator was deduced by subtracting a baseline measurement obtained with just the electrolyte solution. The results were plotted on a potential drop, E/ $\mathrm{mV}$, versus current density, $j / \mathrm{mA} \mathrm{cm}^{-2}$, graph for comparison. All tests were carried out at $296 \pm 2 \mathrm{~K}$. Commercially available separators, chosen for their suitability in electrochemical devices where acidic media are present, were identified and selected for testing (Table 1).

Cyclic voltammetry was conducted using a three-compartment, three-electrode glass cell containing $100 \mathrm{~cm}^{3}$ of electrolyte. A glassy-carbon rotating disc electrode (RDE), with an active area of $0.13 \mathrm{~cm}^{2}$, was used as the working electrode and a platinum mesh was inserted as the counter. Potentials were measured relative to a saturated calomel electrode (SCE) via a Luggin capillary, with the tip placed approximately $2 \mathrm{~mm}$ below the RDE surface. The temperature was maintained at $298 \mathrm{~K}$ using a water bath and the voltammetry was controlled by an Autolab potentiostat, with Nova 1.11 software. Before each test, the working electrode was polished using alumina AP-D suspension $(1 \mu \mathrm{m}$, then $0.3 \mu \mathrm{m}$, Struers) on a surface of moistened polishing cloth, and then rinsed and cleaned using deionised water.

An electrochemical cell with $9 \mathrm{~cm}^{2}$ electrodes has previously been described for cycling tests using static electrolytes [5]. In Sect. 4.3, this cell is converted into a $9 \mathrm{~cm}^{2}$ flow cell with a flow-by electrode configuration by connecting the internal Perspex chambers to Erlenmeyer flasks housing the electrolytes with polymer tubing. A peristaltic pump circulated the electrolyte around the circuit. To measure the potential of an individual electrode, a capillary connected the adjacent Perspex flow chamber to an external test tube, allowing electrolyte to flow in. An SCE was submerged into the electrolyte in the test tube before the beaker was hermetically sealed (Fig. 1b). Separate electrical connections could then be made in order to measure the potential of each electrode against the SCE.

A filter-press flow cell, designed for the soluble lead system by C-Tech Innovation Ltd., was used for further cycling studies. The cell design allowed the use of a separator, differing from soluble lead flow battery cells

Table 1 Separators selected for testing for use in the soluble lead flow cell

\begin{tabular}{llc}
\hline Separator & Type & $\begin{array}{l}\text { Dry } \\
\text { thickness/ } \\
\mu \mathrm{m}\end{array}$ \\
\hline AmerSil FF60 & Microporous separator & 650 \\
Fumatech FAP-450 & Anion exchange membrane & 50 \\
Fumatech VPX-20 & Anion exchange membrane & 30 \\
Fumatech F-930 & Cation exchange membrane & 30 \\
DuPont Nafion 115 & Proton exchange membrane & 100 \\
\hline
\end{tabular}

The thickness when dry was calculated using Vernier callipers reported in the literature [9]. The active area of the electrodes was $100 \mathrm{~cm}^{2}(10 \times 10 \mathrm{~cm})$ and the inter-electrode gap equalled $8 \mathrm{~mm}$. A flow-by electrode configuration was used for the flow path. A separator was compressed between two silicone gaskets, which were then compressed between two inner polypropylene electrode frames. On the inner surface of these frames, grooves for the flow channels were machined into and out of the electrode section. Two adjacent outer polypropylene plates held the brass current collectors, and two stainless steel end plates provide the necessary compression with 12 steel bolts. When assembled, the total width from end plate to end plate was $5.7 \mathrm{~cm}$. The cell height and length equalled 34 and $22 \mathrm{~cm}$, respectively.

\section{Configuration}

When considering the insertion of a cell separator into SLFB, three configurations become possible: the undivided, the semi-divided, and the fully divided, which are illustrated in Fig. 1. The undivided system (Fig. 1a) is the traditional design, without a separator, whose performance is limited by the effects of abnormal deposit growths making electrical contact [7]. The semi-divided configuration, shown in Fig. 1b, divides the cell using a separator, but, like in the undivided set-up, the same electrolyte flows through each half-cell. This provides the benefits of a single tank, pump, and flow system compared to a fully divided configuration. The separator in the semi-divided configuration offers a physical barrier to unwanted deposit growth and electrical shorting in the cell. As the dividing barrier is not required to be ion selective as a single electrolyte is still utilised, a lower cost microporous separator could be used. There is also no concern of concentration gradients or membrane crossover of electrolyte species. However, as in the undivided case, electrode-specific additives will still need to be non-active at the opposite electrode. Figure 1c presents the schematic of the fully divided system, which is analogous to typical redox flow batteries, such as the all-vanadium and zinc-bromine systems. The cell is divided with a separator, allowing the use of electrode-bespoke electrolyte compositions. Electrode-specific additives can also be confined in the target half-cell without interfering with the reactions at the other side. In addition, the separator also acts as a barrier to shorting. However, in practice, crossover of some species is inevitable in the long run, and inefficiencies can cause $\left[\mathrm{Pb}^{2+}\right]$ imbalance between the half-cells. The effect of these designs on cell performance (efficiency and cycle life before failure) is compared in this paper. 


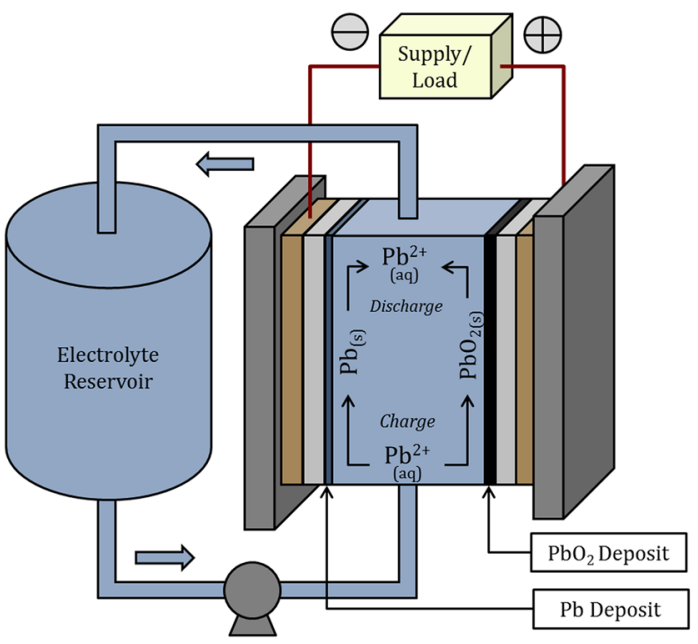

(a)

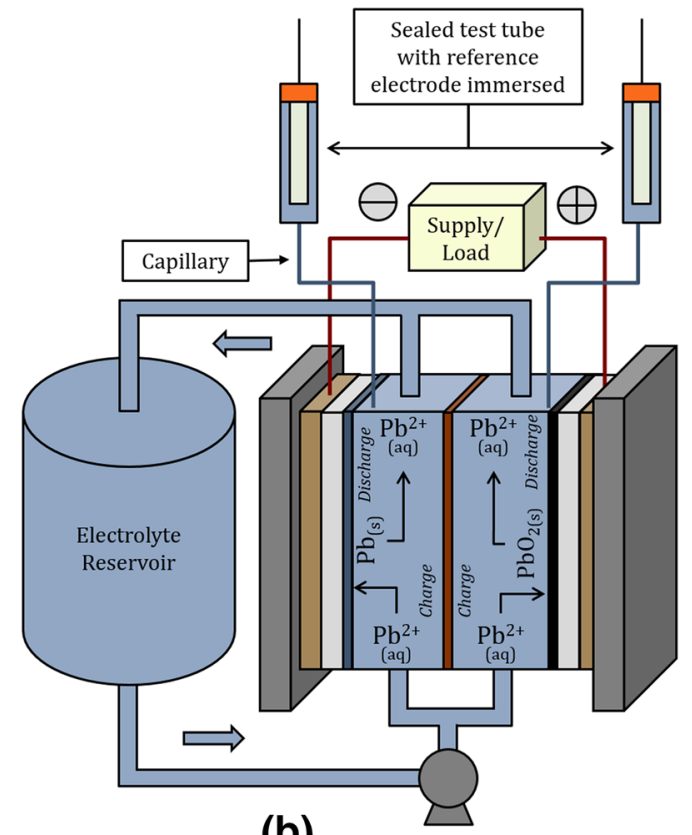

(b)

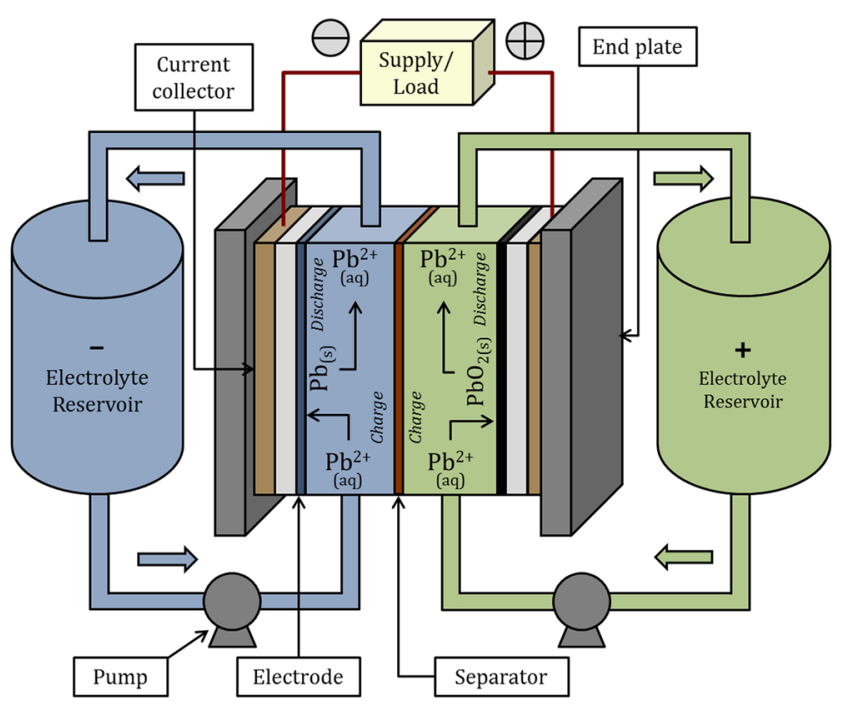

(c)

Fig. 1 Simplified schematics of a single soluble lead flow cell: a standard undivided configuration, where a pump is used to circulate electrolyte around the system. During charge, $\mathrm{Pb}^{2+}$ ions are oxidised at the positive electrode to form solid $\mathrm{PbO}_{2}$ and reduced at the negative electrode to form solid $\mathrm{Pb}$. The process is reversed during dis-

\section{Results and discussion}

\subsection{Separator selection}

Each of the cell separators was assessed by fitting them into the glass test cell and measuring the potential drop associated charge; b semi-divided configuration, where a separator divides the half-cells, but the same electrolyte is circulated through each halfcell; c fully divided configuration, where a separator divides the halfcells and two different electrolytes can be circulated through the cell

with incremental currents applied between the electrodes either side of the membrane. The membranes were assessed in a series of electrolytes, representing different states of charge in the SLFB. The $\mathrm{Pb}^{2+}$ concentration was varied in increments from $0.7 \mathrm{~mol} \mathrm{dm}^{-3}$ to zero with the MSA concentration being varied from 1.0 to $2.4 \mathrm{~mol} \mathrm{dm}^{-3}$, in accordance with Eq. 3. The potential drop across the FF60, FAP-40, VPX-20, 
F-930, and Nafion 115 separators is presented in Fig. 2. The resistance of each separator was expected to decrease with decreasing concentrations of $\mathrm{Pb}^{2+}$, due to the increase in proton concentration within the pores, and this was the generally observed result, particularly for the cation exchange membranes. Between 0 and $100 \% \mathrm{~Pb}^{2+}$ utilisation, the potential drop across the Nafion membrane decreased approximately linearly from 205 to $44 \mathrm{mV}$ at $171 \mathrm{~mA} \mathrm{~cm}^{-2}$. For perspective, a loss of $205 \mathrm{mV}$ represents a $13.7 \%$ voltage loss if assuming a cell potential of $1.5 \mathrm{~V}$ [1]. Over the same $\mathrm{Pb}^{2+}$ utilisation range and current density, the potential drop across the FF60 microporous separator reduced from 125 to $59 \mathrm{mV}$.

The anion exchange membranes were not as sensitive to a change in electrolyte composition: the potential drop across the FAP-450 membrane decreased from 55 to $30 \mathrm{mV}$ between 0 and $100 \% \mathrm{~Pb}^{2+}$ utilisation at $171 \mathrm{~mA} \mathrm{~cm}^{-2}$. Over the same $\mathrm{Pb}^{2+}$ utilisation range and current density, the potential drop across the VPX-20 membrane remained relatively constant, fluctuating between $10 \mathrm{mV}$ (at $33 \%$ utilisation) and $32 \mathrm{mV}$ (at zero utilisation). In general, the anion exchange membranes, VPX-20 and FAP-450, showed the least resistance across the four solutions, followed by the F-930, FF60, and Nafion separators. At $100 \% \mathrm{~Pb}^{2+}$ utilisation, the potential drops of all separators, even at the higher current density, were comparable and below $60 \mathrm{mV}$.

The total ohmic resistance associated with each membrane and electrolyte composition is shown in Table 2, with the thickness-normalised resistance presented in Table 3. With all the electrolyte compositions, the VPX-20 offered the lowest total resistance $(85-170 \mathrm{~m} \Omega$ ); however,

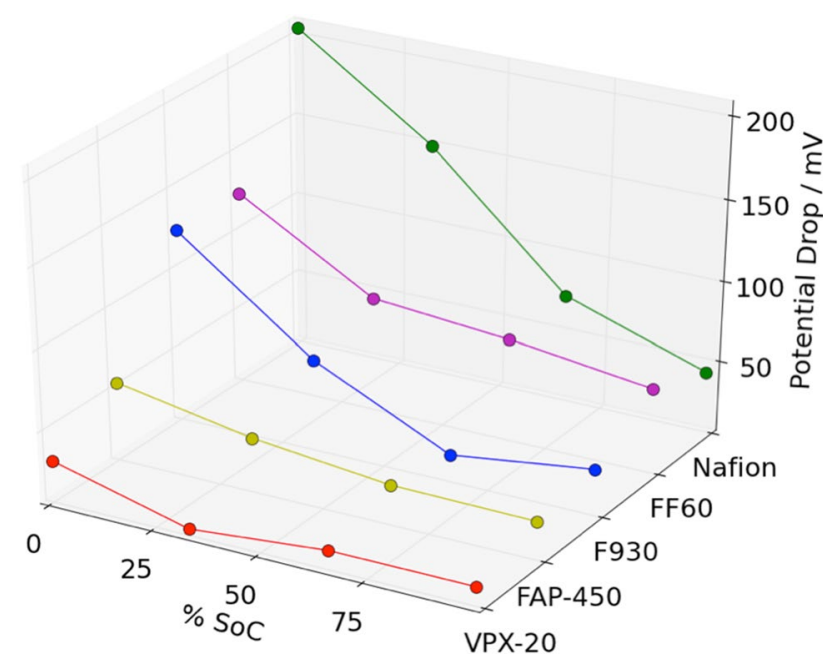

Fig. 2 Potential drops at $170 \mathrm{~mA} \mathrm{~cm}{ }^{-2}$ across five separators at four different \% states of charge (SoC): $0 \%: 0.7 \mathrm{~mol} \mathrm{dm}^{-3} \mathrm{~Pb}\left(\mathrm{CH}_{3} \mathrm{SO}_{3}\right)_{2}$ and $1.0 \mathrm{~mol} \mathrm{dm}^{-3} \mathrm{CH}_{3} \mathrm{SO}_{3} \mathrm{H}$; 33\%: $0.46 \mathrm{~mol} \mathrm{dm}^{-3} \mathrm{~Pb}\left(\mathrm{CH}_{3} \mathrm{SO}_{3}\right)_{2}$ and $1.48 \mathrm{~mol} \mathrm{dm}^{-3} \mathrm{CH}_{3} \mathrm{SO}_{3} \mathrm{H}$; $66 \%$ : $0.23 \mathrm{~mol} \mathrm{dm}^{-3} \mathrm{~Pb}\left(\mathrm{CH}_{3} \mathrm{SO}_{3}\right)_{2}$ and $1.94 \mathrm{~mol} \mathrm{dm}^{-3} \mathrm{CH}_{3} \mathrm{SO}_{3} \mathrm{H} ; 100 \%: 0 \mathrm{~mol} \mathrm{dm}^{-3} \mathrm{~Pb}\left(\mathrm{CH}_{3} \mathrm{SO}_{3}\right)_{2}$ and $2.4 \mathrm{~mol} \mathrm{dm}^{-3} \mathrm{CH}_{3} \mathrm{SO}_{3} \mathrm{H}$
Table 2 Separator resistances as a function of electrolyte composition, calculated from the potential drop measurements presented in Fig. 2

\begin{tabular}{llllll}
\hline $\begin{array}{l}\text { \% } \mathrm{Pb}^{2+} \\
\text { utilisation }\end{array}$ & \multicolumn{4}{l}{ Resistance/m $\Omega$} \\
\cline { 2 - 6 } & F-930 & FAP 450 & VPX-20 & FF60 & Nafion \\
\hline 0 & 753 & 263 & 170 & 638 & 1028 \\
33 & 318 & 190 & 75 & 393 & 708 \\
66 & 143 & 168 & 95 & 345 & 358 \\
100 & 173 & 150 & 85 & 293 & 225 \\
\hline
\end{tabular}

0\%: $0.7 \mathrm{~mol} \mathrm{dm}^{-3} \mathrm{~Pb}\left(\mathrm{CH}_{3} \mathrm{SO}_{3}\right)_{2}$ and $1.0 \mathrm{~mol} \mathrm{dm}^{-3} \mathrm{CH}_{3} \mathrm{SO}_{3} \mathrm{H} ; 33 \%$ : $0.46 \mathrm{~mol} \mathrm{dm}^{-3} \mathrm{~Pb}\left(\mathrm{CH}_{3} \mathrm{SO}_{3}\right)_{2}$ and $1.48 \mathrm{~mol} \mathrm{dm}^{-3} \mathrm{CH}_{3} \mathrm{SO}_{3} \mathrm{H} ; 66 \%$ : $0.23 \mathrm{~mol} \mathrm{dm}^{-3} \mathrm{~Pb}\left(\mathrm{CH}_{3} \mathrm{SO}_{3}\right)_{2}$ and $1.94 \mathrm{~mol} \mathrm{dm}^{-3} \mathrm{CH}_{3} \mathrm{SO}_{3} \mathrm{H} ; 100 \%$ : $0 \mathrm{~mol} \mathrm{dm}^{-3} \mathrm{~Pb}\left(\mathrm{CH}_{3} \mathrm{SO}_{3}\right)_{2}$ and $2.4 \mathrm{~mol} \mathrm{dm}^{-3} \mathrm{CH}_{3} \mathrm{SO}_{3} \mathrm{H}$

when normalised to take into account the membrane thickness, Nafion (2.3-10.3 $\Omega \mathrm{mm}^{-1}$ ) returned similar resistance values to VPX-20 $\left(2.8-5.7 \Omega \mathrm{mm}^{-1}\right)$, while FF60 $\left(0.5-1.0 \Omega \mathrm{mm}^{-1}\right)$ returned the lowest resistance. It is interesting to note that VPX-20 is an anion exchange membrane compared to the cation exchange Nafion. For this proof-of-concept study, VPX-20 was chosen due to having the lowest total resistance. In the electrolytes used, it is unclear if the ionic conductivity of VPX-20 is purely from the $\mathrm{CH}_{3} \mathrm{SO}_{3}{ }^{-}$anion or from bulk electrolyte transport. For future development of the system, the resistance and species crossover will need to be investigated further to identify the most suitable membrane. Likewise, if the semi-divided system is developed, microporous separators such as FF60 could be investigated further.

\subsection{The effect of additives on the kinetics of the $\mathrm{Pb}^{2+} / \mathrm{PbO}_{2}$ couple}

Incorporating a separator into the SLFB allows for electrodespecific additives to be used in the electrolyte. The electrochemical performance of the positive half-cell is limited by

Table 3 Separator resistances as a function of electrolyte composition and separator thickness, calculated from the potential drop measurements presented in Fig. 2 and width measurements presented in Table 1

\begin{tabular}{|c|c|c|c|c|c|}
\hline \multirow{2}{*}{$\begin{array}{l}\% \mathrm{~Pb}^{2+} \\
\text { utilisation }\end{array}$} & \multicolumn{5}{|c|}{ Resistance $/ \Omega \mathrm{mm}^{-1}$} \\
\hline & F-930 & FAP 450 & VPX-20 & FF60 & Nafion \\
\hline 0 & 25.1 & 5.3 & 5.7 & 1.0 & 10.3 \\
\hline 33 & 10.6 & 3.8 & 2.5 & 0.6 & 7.1 \\
\hline 66 & 4.8 & 3.4 & 3.2 & 0.5 & 3.6 \\
\hline 100 & 5.8 & 3.0 & 2.8 & 0.5 & 2.3 \\
\hline
\end{tabular}

0\%: $0.7 \mathrm{~mol} \mathrm{dm}^{-3} \mathrm{~Pb}\left(\mathrm{CH}_{3} \mathrm{SO}_{3}\right)_{2}$ and $1.0 \mathrm{~mol} \mathrm{dm}^{-3} \mathrm{CH}_{3} \mathrm{SO}_{3} \mathrm{H} ; 33 \%$ : $0.46 \mathrm{~mol} \mathrm{dm}^{-3} \mathrm{~Pb}\left(\mathrm{CH}_{3} \mathrm{SO}_{3}\right)_{2}$ and $1.48 \mathrm{~mol} \mathrm{dm}^{-3} \mathrm{CH}_{3} \mathrm{SO}_{3} \mathrm{H} ; 66 \%$ : $0.23 \mathrm{~mol} \mathrm{dm}^{-3} \mathrm{~Pb}\left(\mathrm{CH}_{3} \mathrm{SO}_{3}\right)_{2}$ and $1.94 \mathrm{~mol} \mathrm{dm}^{-3} \mathrm{CH}_{3} \mathrm{SO}_{3} \mathrm{H} ; 100 \%$ : $0 \mathrm{~mol} \mathrm{dm}^{-3} \mathrm{~Pb}\left(\mathrm{CH}_{3} \mathrm{SO}_{3}\right)_{2}$ and $2.4 \mathrm{~mol} \mathrm{dm}^{-3} \mathrm{CH}_{3} \mathrm{SO}_{3} \mathrm{H}$ 
the reaction kinetics of the $\mathrm{Pb}^{2+} / \mathrm{PbO}_{2}$ couple. Additives that increase the kinetics of this reaction and improve electrical conductivity of the $\mathrm{PbO}_{2}$ deposit are, therefore, of particular interest for the SLFB. Using the three-compartment glass cell, 50 consecutive cyclic voltammograms were conducted with each additive. Additives have previously been reported for use in the soluble lead literature, for example, bismuth [12], fluoride [12-14] and nickel(II) [4], and novel additives tin(II) oxide, EDTA, gadolinium(III) oxide, and zinc(II) oxide were compared. PVP was also studied due to its use in controlling the particle size of $\mathrm{PbO}_{2}$ coatings [15]. The potential was initially swept towards positive potentials from 0.2 to $1.9 \mathrm{~V}$ in the forward scan and then back to $0.2 \mathrm{~V}$. A sweep rate of $50 \mathrm{mV} \mathrm{s}^{-1}$ was used throughout. The RDE rotation rate was $750 \mathrm{rpm}$. The equilibrium potential, $E^{\mathrm{e}}$, for the $\mathrm{Pb}^{2+} / \mathrm{PbO}_{2}$ couple is estimated from the voltammograms and is provided for each of the additives in Table 4. It should be noted that additives have a varied impact on the equilibrium potential, ranging from a negative shift of $80 \mathrm{mV}$ for $\mathrm{F}^{-}$to a positive shift of $90 \mathrm{mV}$ for $\mathrm{Bi}^{3+}$ compared to the electrolyte with no additives. A negative shift will reduce the cell potential in the SLFB, while a positive shift increases the cell voltage.

The 50th cycle of each test was analysed further. On the reverse scan of this cycle, the proportion of the $\mathrm{PbO}_{2}$ deposit stripped as a function of the cathodic overpotential, $\eta$, was calculated relative to $100 \%$ dissolution at the lower potential limit at $0.2 \mathrm{~V}$. This is presented in Table 5 for overpotentials ranging from 100 to $500 \mathrm{mV}$. The additives are ordered by their effect on the equilibrium potential, $E^{\mathrm{e}}$, of the $\mathrm{Pb}^{2+}$ / $\mathrm{PbO}_{2}$ couple (Table 4). Consider the data for the electrolyte with no additive: the dissolution of the $\mathrm{PbO}_{2}$ occurs between 1.55 and $0.2 \mathrm{~V}$ versus SCE. $23 \%$ of the dissolution

Table 4 Effect of additives on the equilibrium potential, $E^{\mathrm{e}}$, of the $\mathrm{Pb}^{2+} / \mathrm{PbO}_{2}$ redox couple, discerned by cyclic voltammetry

\begin{tabular}{lll}
\hline Additive & {$[$ Additive]/mM } & $E^{\mathrm{e} / \mathrm{V}}$ \\
\hline $\mathrm{F}^{-}$ & 60 & 1.48 \\
$\mathrm{Sn}^{2+}$ & 15 & 1.50 \\
$\mathrm{EDTA}$ & 15 & 1.50 \\
$\mathrm{Ni}^{2+}$ & 50 & 1.52 \\
$\mathrm{PVP}$ & $1 \mathrm{~g} \mathrm{dm}^{-3}$ & 1.54 \\
- & - & 1.55 \\
$\mathrm{Gd}^{3+}$ & 15 & 1.56 \\
$\mathrm{Zn}^{2+}$ & 50 & 1.62 \\
$\mathrm{Bi}^{3+}$ & 15 & 1.64 \\
\hline
\end{tabular}

Cycle 50, potential range $0.2-1.9 \mathrm{~V}$ versus SCE, electrolyte: $0.7 \mathrm{M}$ $\mathrm{Pb}^{2+}$ and 1.0 M MSA. Electrodes: RDE glassy carbon, counter platinum mesh, reference SCE. Scan rate: $50 \mathrm{mV} \mathrm{s}^{-1}$, rotation rate: $750 \mathrm{rpm}$, temperature: $298 \mathrm{~K}$

EDTA ethylenediaminetetraacetic acid disodium salt, $P V P$ polyvinylpyrrolidone process occurs by $1.25 \mathrm{~V}$, i.e., $\eta=300 \mathrm{mV}$, and $53 \%$ of all dissolution occurs by $1.05 \mathrm{~V}$, i.e. $\eta=500 \mathrm{mV}$. This provides an indication on the behaviour of the cell potential during discharge. If a larger percentage of deposit is dissolved at a lower overpotential, the cell potential will remain higher for longer during discharge and the overall voltage efficiency will be higher.

The addition of $\mathrm{F}^{-}, \mathrm{Sn}^{2+}$, EDTA, $\mathrm{Ni}^{2+}$ or PVP decreases the equilibrium potential below $1.55 \mathrm{~V}$, whilst the presence of $\mathrm{Zn}^{2+}$ and $\mathrm{Bi}^{3+}$ results in a rise above $1.6 \mathrm{~V}$, which would increase the cell potential during cycling. It can be seen that with EDTA in solution, only $42 \%$ of the deposit had been dissolved at an overpotential of $500 \mathrm{mV}$. It should be noted that up to $98 \%$ of the deposit had been removed at an overpotential of $750 \mathrm{mV}$; however, this would result in the cell discharge potential dropping rapidly to an impractically low value. EDTA was, therefore, ruled out.

The amount of deposit stripping at $\eta=500 \mathrm{mV}$ increases from $53 \%$ with no additive to $70 \%$ with $\mathrm{Bi}^{3+}$ in solution; more of the deposit is stripped at lower overpotentials based around a higher equilibrium potential, which would suggest a higher discharge potential being maintained for a longer time than without the additive. This voltammogram has previously been published [12]. A similar conclusion, though to a lesser extent, can be made with $\mathrm{Zn}^{2+}$-containing electrolytes.

Aside from the $\mathrm{Sn}^{2+}$ test, all tests saw $>80 \%$ stripping at an overpotential of $750 \mathrm{mV}$ or greater. With $\mathrm{Sn}^{2+}$ in solution, $25 \%$ of stripping occurred beyond $750 \mathrm{mV}$, which could result in the cell potential cutoff being reached before the deposit has been sufficiently stripped, leading to a build-up

Table 5 Percentage of $\mathrm{PbO}_{2}$ deposit stripped as a function of overpotential, $\eta$, (relative to $100 \%$ stripping by $0.2 \mathrm{~V}$ ) at cycle 50 of 50 consecutive cyclic voltammograms

\begin{tabular}{lllrrr}
\hline \multicolumn{5}{c}{$\eta / \mathrm{mV}$} \\
\hline Add & [Add] & 100 & 200 & 300 & 500 \\
$\mathrm{~F}^{-}$ & $60 \mathrm{mM}$ & 4 & 16 & 27 & 57 \\
$\mathrm{Sn}^{2+}$ & $15 \mathrm{mM}$ & 1 & 13 & 44 & 66 \\
$\mathrm{EDTA}$ & $15 \mathrm{mM}$ & $<1$ & 2 & 6 & 42 \\
$\mathrm{Ni}^{2+}$ & $50 \mathrm{mM}$ & 5 & 16 & 32 & 66 \\
$\mathrm{PVP}$ & $1 \mathrm{~g} \mathrm{dm}^{-3}$ & 4 & 14 & 28 & 58 \\
- & - & 4 & 12 & 23 & 53 \\
$\mathrm{Gd}^{3+}$ & $15 \mathrm{mM}$ & 4 & 12 & 23 & 52 \\
$\mathrm{Zn}^{2+}$ & $50 \mathrm{mM}$ & 8 & 22 & 35 & 64 \\
$\mathrm{Bi}^{3+}$ & $15 \mathrm{mM}$ & 7 & 24 & 43 & 70 \\
\hline
\end{tabular}

Potential range $0.2-1.9 \mathrm{~V}$ versus SCE, electrolyte: $0.7 \mathrm{M} \mathrm{Pb}^{2+}$ and 1.0 M MSA. Electrodes: RDE glassy carbon, counter platinum mesh, reference SCE. Scan rate: $50 \mathrm{mV} \mathrm{s}^{-1}$, rotation rate: $750 \mathrm{rpm}$, temperature: $298 \mathrm{~K}$

EDTA ethylenediaminetetraacetic acid disodium salt, PVP polyvinylpyrrolidone 
of the deposit with each cycle. $\mathrm{Sn}^{2+}$, therefore, would not make a suitable additive for the system. $\mathrm{Gd}^{3+}$ clearly does not have any impact on the mechanism, as the data almost exactly match that of the no-additive test. PVP also has a little effect on the stripping of $\mathrm{PbO}_{2}$, only slightly increasing the $\%$ stripping at each overpotential, for example 58\% compared to $53 \%$ (no additive) at $\eta=500 \mathrm{mV}$. There is some improvement with $\mathrm{Ni}^{2+}$ present: based on comparable equilibrium potentials, $66 \%$ stripping occurs at an overpotential of $500 \mathrm{mV}$ compared to $53 \%$ in the no-additive test. However, there is no increase in the equilibrium potential as seen in tests containing $\mathrm{Zn}^{2+}$ or $\mathrm{Bi}^{3+}$. In summary, $\mathrm{Bi}^{3+}$ offers the dual advantage of increasing the $\mathrm{Pb}^{2+} / \mathrm{PbO}_{2}$ equilibrium and increasing the percentage of deposit stripped as a function of overpotential and is selected as an additive for the positive electrode reaction in the flow cell.

\subsection{Flow cell configuration comparison $\left(9 \mathrm{~cm}^{2}\right.$ flow cell)}

The $9 \mathrm{~cm}^{2}$ flow cell was used to compare the three different cell configurations. The VPX-20 membrane was used in each of the semi- and fully divided tests. The additives

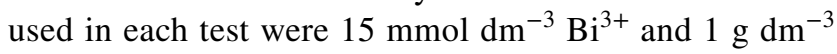
lignosulfonate, the latter being previously reported for the negative electrode reaction in the SLFB [4]. In the fully divided format, the lignosulfonate was added only to the negative Erlenmeyer flask, with the bismuth only added to the positive. First, 20 charge/discharge cycles were implemented. Each cycle consisted of a charge phase for $63 \mathrm{~min}$ at $20 \mathrm{~mA} \mathrm{~cm}^{-2}$, followed by a $3 \mathrm{~min}$ open-circuit rest period, subsequent discharge to $0.7 \mathrm{~V}$ (with a time cutoff of $63 \mathrm{~min}$ ) at the same current density, followed by another 3 min rest period. Using Faraday's Law, the charge supplied on each charging period was calculated to amount to a $5 \% \mathrm{~Pb}^{2+}$ utilisation when using $200 \mathrm{~cm}^{3}$ of a solution initially containing $0.7 \mathrm{~mol} \mathrm{dm}^{-3} \mathrm{~Pb}\left(\mathrm{CH}_{3} \mathrm{SO}_{3}\right)_{2}$. Following these 20 cycles at $20 \mathrm{~mA} \mathrm{~cm}{ }^{-2}$, the experiment was continued for a further 9 cycles with the current density being incremented at each cycle, with the charge/discharge time shortened on each subsequent cycle to amount to a $10 \% \mathrm{~Pb}^{2+}$ level of utilisation: cycles 21-26 correspond to current densities of 20, 35, 50, 65,80 , and $100 \mathrm{~mA} \mathrm{~cm}^{-2}$, respectively. This is equivalent to depositing 0.014 moles of $\mathrm{Pb}^{2+}$ onto the electrodes (0.007 moles onto each electrode respectively). This second phase of cycling tested the resilience of the cell to the failure mechanisms accelerated by the higher currents, such as dendrite growth, lead dioxide creep, and the effect of poor deposition quality on charge efficiency. The flow rate in all experiments was maintained at $2.3 \mathrm{~cm} \mathrm{~s}^{-1}$ across each electrode surfaces, equivalent to a volumetric flow rate of $4.48 \mathrm{~cm}^{3} \mathrm{~s}^{-1}$. Experiments took place under ambient temperature, 296 K. Figure 3 presents the charge and voltage efficiency of each of the first 50 cycles of the undivided, semi-divided, and fully divided formats.

The undivided configuration performs well over the first cycles, peaking at $97 \%$ charge efficiency at the ninth cycle. However, following the tenth cycle, a sudden drop in charge efficiency is observed. In each cycle after this point, the potential-time profile of the undivided experiment showed signs of electrical shorting during the charge phase as a result of the contact between lead and lead dioxide deposits. The charge efficiency drops due to a lack of deposition, but the voltage efficiency remains fairly constant, averaging $60 \%$ across the first 20 cycles, after which this cell was stopped. When the cell was dismantled, there were clear signs of deposit contact following growth along the lower surface of the internal cell wall. This occurrence has previously been described and photographed [8]. The separator in the semi- and fully divided configurations successfully prevents any shorting from occurring. The charge efficiency of the semi-divided configuration remains high (above 80\%) between cycles 10 and 45 . Between cycles 45 and 50, the charge efficiency again drops due to the onset of cell failure. The fully divided configuration maintained a charge efficiency above $80 \%$ beyond the 50 cycle mark, outlasting both the undivided and semi-divided configurations. The overall voltage efficiencies of the three configurations are comparable and show a little variation with cycle number, averaging roughly $63 \%$ across the 50 cycles.

Following the initial cycling, semi-, and fully divided configuration testing was continued to investigate the effect of higher current densities on cell performance. This is seen in Fig. 4. As the current is increased from 20 to $100 \mathrm{~mA} \mathrm{~cm}^{-2}$ between cycles 21 and 29, the charge efficiency decreases in the experiments. Performance is generally good, with $>70 \%$ charge efficiency achievable when charging and discharging below $65 \mathrm{~mA} \mathrm{~cm}^{-2}$. Even $65 \%$ is achieved at $100 \mathrm{~mA} \mathrm{~cm}^{-2}$, suggesting that the soluble lead system could operate for short durations (minutes) at relatively high currents compared to other flow battery chemistries, which would be suitable for a renewable integration application. From these experiments, there is no clear difference between a semi-divided and fully divided soluble lead system in terms of efficiency.

The voltage efficiency follows a decreasing trend in the semi-divided and fully divided tests, from approximately $70 \%$ at $20 \mathrm{~mA} \mathrm{~cm}^{-2}$, down to 46 and $39 \%$ at $100 \mathrm{~mA} \mathrm{~cm}^{-2}$ for the semi- and fully divided tests respectively. It is not clear why the semi-divided test offers a better voltage efficiency than the fully divided test (averaging $8 \%$ points at each cycle), but this leads to slightly greater energy efficiencies in the semi-divided cell at all current densities higher than $20 \mathrm{~mA} \mathrm{~cm}^{-2}$.

While both the semi- and fully divided configurations offer the advantage of reduced cell failure from electrical 
Fig. 3 Cycles $1-50$ of the separator configuration study. The efficiency of each cycle is presented: a charge and $\mathbf{b}$ voltage. Electrolyte: $0.7 \mathrm{~mol} \mathrm{dm}^{-3}$ $\mathrm{Pb}\left(\mathrm{CH}_{3} \mathrm{SO}_{3}\right)_{2}$ and $1.0 \mathrm{~mol}$ $\mathrm{dm}^{-3} \mathrm{CH}_{3} \mathrm{SO}_{3} \mathrm{H}$. Additives: $15 \mathrm{mmol} \mathrm{dm}^{-3} \mathrm{Bi}^{3+}$ (+ve only in fully divided) and $1 \mathrm{~g} \mathrm{dm}^{-3}$ lignosulfonate (-ve only in fully divided). Separator: VPX20. Electrode: $9 \mathrm{~cm}^{2}$, carbon/ polyvinyl ester. Cycling regime: $63 \mathrm{~min}$ charge at $20 \mathrm{~mA} \mathrm{~cm}^{-2}$, 3 min rest, discharge to $0.7 \mathrm{~V}$ (or max $63 \mathrm{~min}$ ) at $20 \mathrm{~mA}$ $\mathrm{cm}^{-2}, 3$ min rest. Electrolyte volume: $200 \mathrm{~cm}^{3}$. Flow rate: $2.3 \mathrm{~cm} \mathrm{~s}^{-1}$. Temperature: $296 \mathrm{~K}$

Fig. 4 Cycles 21-29 of the separator configuration study, where the current density is incremented from 20 to $10 \mathrm{~mA} \mathrm{~cm}^{-2}$. The efficiency of each cycle is presented: a charge and $\mathbf{b}$ voltage. Electrolyte: $0.7 \mathrm{~mol} \mathrm{dm}^{-3}$ $\mathrm{Pb}\left(\mathrm{CH}_{3} \mathrm{SO}_{3}\right)_{2}$ and $1.0 \mathrm{~mol} \mathrm{dm}^{-3}$ $\mathrm{CH}_{3} \mathrm{SO}_{3} \mathrm{H}$. Additives: $15 \mathrm{mmol}$ $\mathrm{dm}^{-3} \mathrm{Bi}^{3+}$ (+ve only in fully divided) and $1 \mathrm{~g} \mathrm{dm}^{-3}$ lignosulfonate (-ve only in fully divided). Separator: VPX-20. Electrode: $9 \mathrm{~cm}^{2}$, carbon/polyvinyl ester. Electrolyte volume: $200 \mathrm{~cm}^{3}$. Flow rate: $2.3 \mathrm{~cm} \mathrm{~s}^{-1}$. Temperature: $296 \mathrm{~K}$ (a)

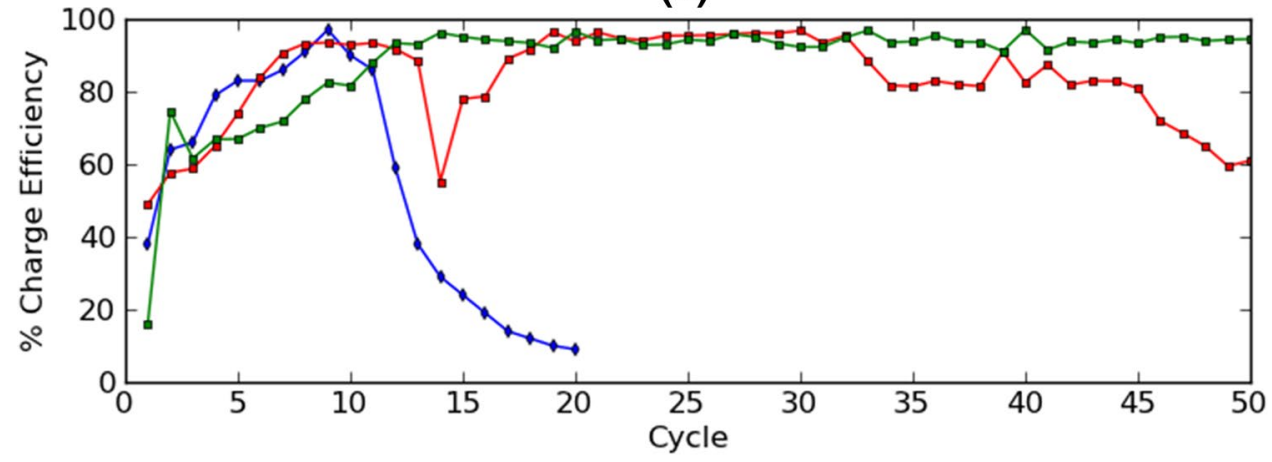

(b)

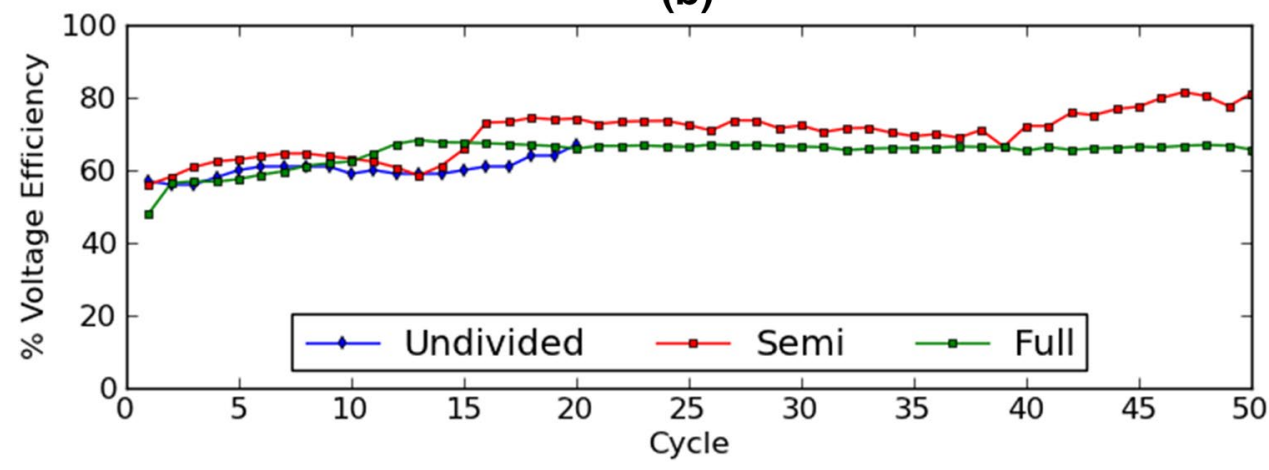

(a)

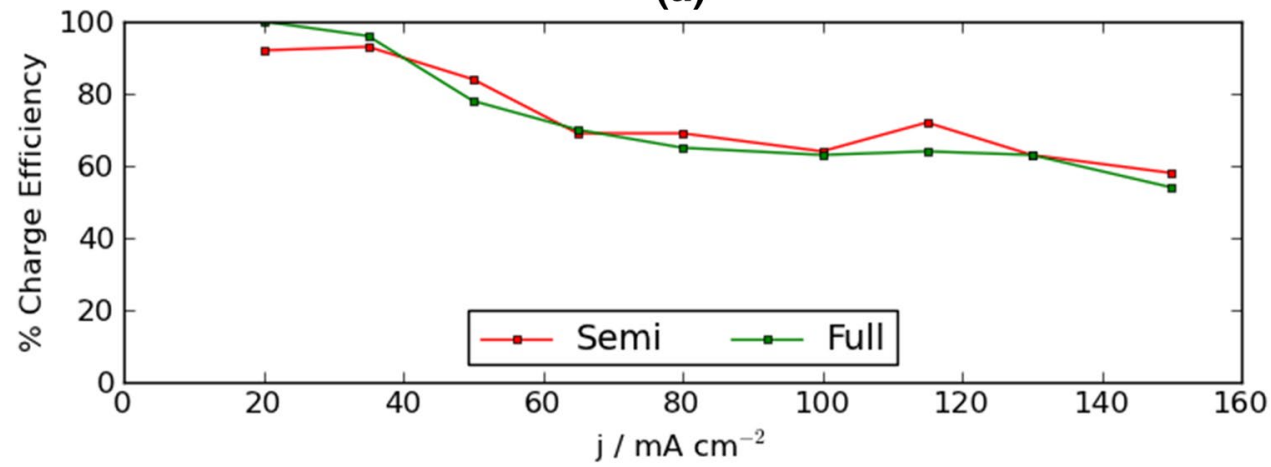

(b)

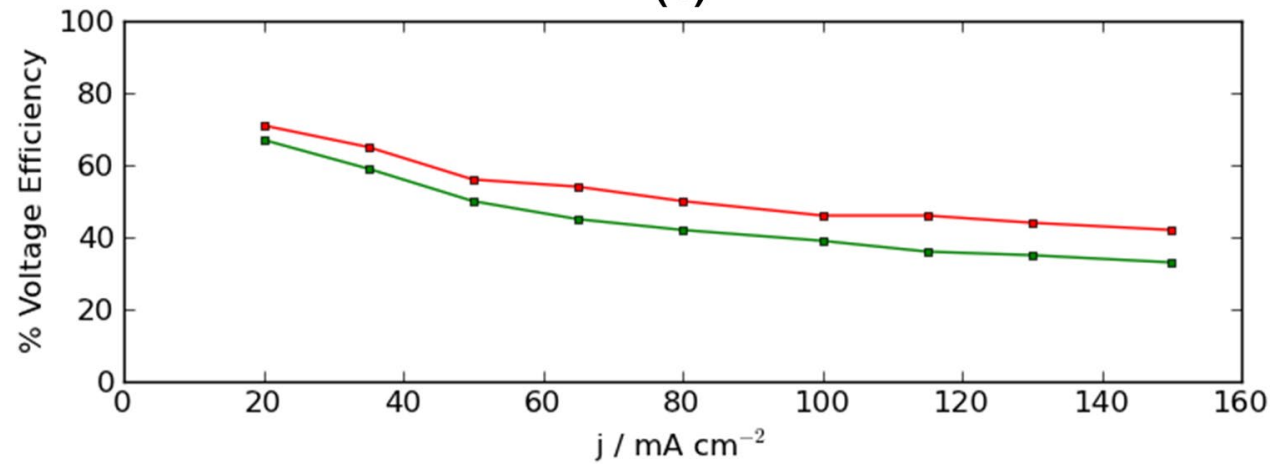


shorting, there are still significant differences between the two configurations. The semi-divided system has the advantage of reduced complexity and a single-electrolyte reservoir and pump circuit, and can operate with microporous separators. The fully divided system is more complex, requiring two electrolyte reservoirs and pump circuits, but offers the advantage of allowing electrode-specific additives. The effect of this can be demonstrated by investigating the individual electrode potentials during charge and discharge. Figure 5 compares the voltage versus time profile for two semidivided flow cells with and without the electrolyte additives $\left(\mathrm{Bi}^{3+}\right.$ and lignosulfonic acid). In Fig. 5a, the cell voltage shows the typical response during charge for an SLFB. During discharge, however, the cell with electrolyte containing additives shows two voltage plateaus. One at circa $1.5 \mathrm{~V}$ followed by the second at circa $1.0 \mathrm{~V}$. The individual halfcell potentials for the negative (6b) and positive (6c) show that the double voltage plateau on discharge is associated with the negative electrode. This is consistent with the voltammetry of $\mathrm{Bi}^{3+}$ containing SLFB electorates previously reported [10] and can be attributed to the co-deposition of a $\mathrm{Pb}-\mathrm{Bi}$ alloy during discharge with the second voltage plateau on discharge resulting from the dissolution of the $\mathrm{Bi}$ material. While, individually, $\mathrm{Bi}^{3+}$ and lignosulphonic acid are beneficial to the positive and negative electrode reactions, respectively [10], they have a detrimental impact on the opposite electrode reactions. The effect of $\mathrm{Bi}^{3+}$ at the negative electrode and lignosulphonic acid at the positive electrode is to decrease the cell discharge voltage and reduce the coulombic efficiency. In the fully divided cell, these effects are prevented as the additives are added to the specific electrolyte reservoirs.

\subsection{Cycling the $100 \mathrm{~cm}^{2}$ flow cell}

The $100 \mathrm{~cm}^{2}$ flow cell was configured in the semi-divided format and put through a series of charge/discharge cycles. $2 \mathrm{dm}^{3}$ of electrolyte overall was used in each experiment, with $15 \mathrm{mmol} \mathrm{dm}{ }^{-3} \mathrm{Bi}^{3+}$ present. Reticulated vitreous carbon (RVC) was introduced to control the growth of deposits along the cell walls: two $10 \times 10 \mathrm{~cm}$ squares of $90 \mathrm{ppi}$; $2 \mathrm{~mm}$-thick RVC were inserted in each half-cell and compressed against the 2D carbon/polyvinyl ester electrode.

The cycling regime was composed of several stages. A single charge/discharge cycle consisted of four phases: $60 \mathrm{~min}$ charge, $10 \mathrm{~min}$ rest, and discharge down to $0.8 \mathrm{~V}$ or for a maximum of $60 \mathrm{~min}, 10 \mathrm{~min}$ rest. The first 22 cycles operated at $20 \mathrm{~mA} \mathrm{~cm}^{-2}$. This was increased to $25 \mathrm{~mA} \mathrm{~cm}^{-2}$ for the following 11 cycles (cycles 23-33), and then to $30 \mathrm{~mA} \mathrm{~cm}^{-2}$ for the 11 cycles after that (cycles 34-44). Finally, the current density was returned to $20 \mathrm{~mA} \mathrm{~cm}^{-2}$ for all subsequent cycles (cycles $45+$ ). The charge associated with $60 \mathrm{~min}$ of a $20 \mathrm{~mA} \mathrm{~cm}^{-2}$ charging phase was sufficient

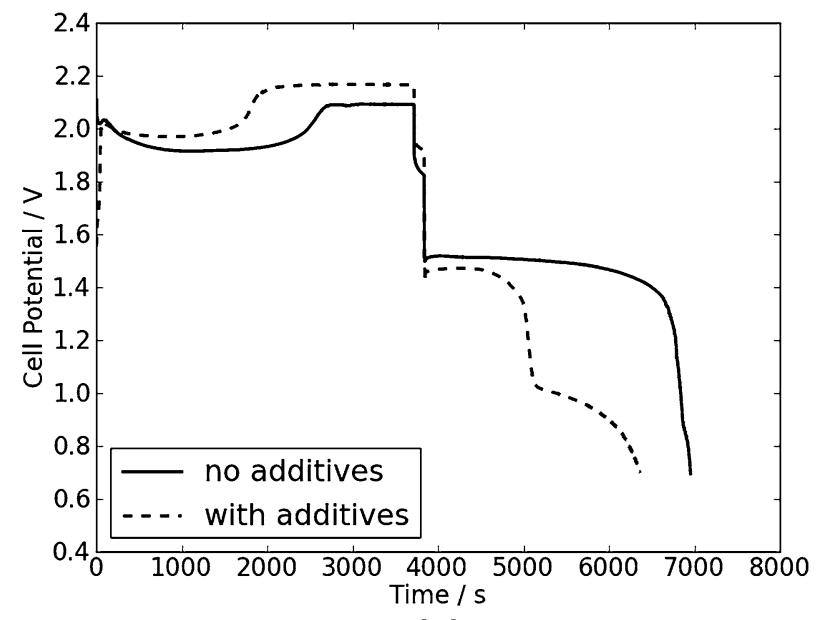

(a)

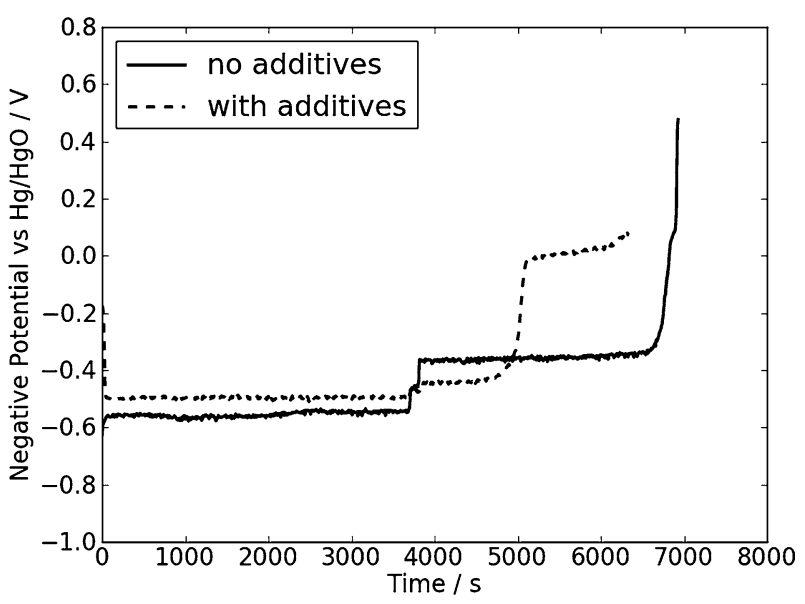

(b)

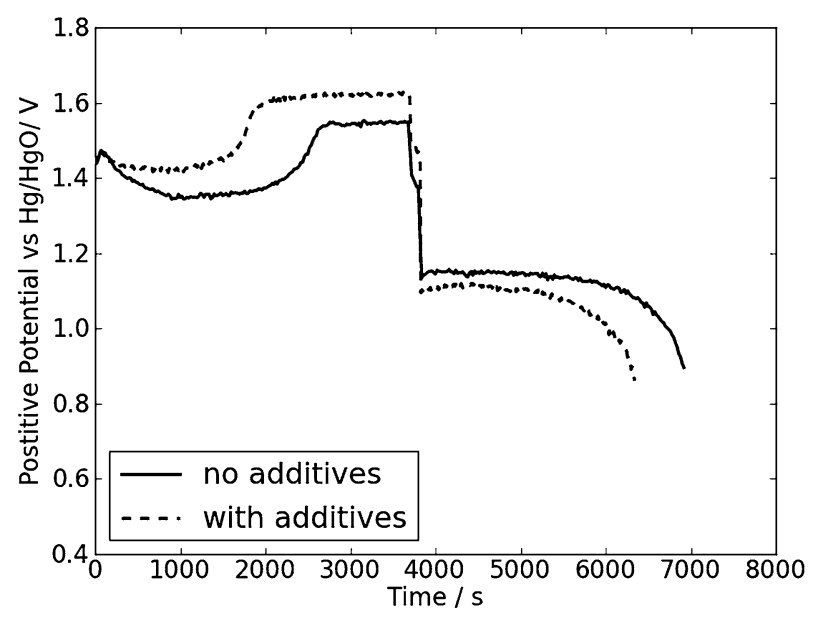

(c)

Fig. 5 Comparison of the effect of the additives: $15 \mathrm{mmol} \mathrm{dm}^{-3}$ $\mathrm{Bi}^{3+}$ and $1 \mathrm{~g} \mathrm{dm}^{-3}$ lignosulfonate on the potential transients of the a cell and $\mathbf{b}$ negative and $\mathbf{c}$ positive electrodes of cycle 5 of the semidivided cycling tests 
Table 6 Average charge (Q), voltage (V), and energy (En) efficiencies when cycling the $100 \mathrm{~cm}^{2}$ flow cell

\begin{tabular}{lllll}
\hline Cycle & $\begin{array}{l}\text { Charge/dis- } \\
\text { charge } j / \mathrm{mA} \\
\text { cm }^{-2}\end{array}$ & Av. \% Q Eff & Av. \% V Eff & Av. \% En Eff \\
\hline $1-22$ & 20 & 84 & 73 & 63 \\
$23-33$ & 25 & 94 & 83 & 78 \\
$34-44$ & 30 & 93 & 83 & 77 \\
$45-150$ & 20 & 87 & 86 & 75 \\
$1-150$ & $20-30$ & 88 & 84 & 73 \\
\hline
\end{tabular}

Charge time: $60 \mathrm{~min}$. Electrolyte: $0.7 \mathrm{~mol} \mathrm{dm}^{-3} \mathrm{~Pb}\left(\mathrm{CH}_{3} \mathrm{SO}_{3}\right)_{2}$ and $1.0 \mathrm{~mol} \mathrm{dm}{ }^{-3} \mathrm{CH}_{3} \mathrm{SO}_{3} \mathrm{H}$. Additives: mol $\mathrm{dm}^{-3} \mathrm{Bi}^{3+}$. Separator: Nafion 115 (semi-divided). Electrode: $100 \mathrm{~cm}^{2}$, carbon/polyvinyl ester, with 90 ppi RVC, compressed with nylon mesh. Electrolyte volume: $2000 \mathrm{~cm}^{3}$. Flow rate: $5.2 \mathrm{~cm} \mathrm{~s}^{-1}$. Temperature: $296 \mathrm{~K}$

for $5 \% \mathrm{~Pb}^{2+}$ utilisation ( 0.037 moles deposited onto each electrode). At $30 \mathrm{~mA} \mathrm{~cm}{ }^{-2}$, this increased to $8 \%(0.056$ moles deposited onto each electrode). The flow rate was initially set to $150 \mathrm{dm}^{3} \mathrm{~h}^{-1}$, or $5.2 \mathrm{~cm} \mathrm{~s}^{-1}$. The results are presented in Table 6. Over 150 cycles were achieved using the semi-divided configuration, totalling $300 \mathrm{~h}$ of operation.

The performance across the early cycles was very similar to the semi-divided test with additives in the $9 \mathrm{~cm}^{2}$ flow. The charge efficiency rose from $34 \%$ at the first cycle to $99 \%$ at the fifth. Overall, $88 \%$ charge efficiency and $84 \%$ voltage efficiency were achieved across the 150 cycles. In comparison, the previously most successful cycling test was conducted by Collins et al. [9], where a $100 \mathrm{~cm}^{2}$ undivided cell was cycled with $1.5 \mathrm{dm}^{3}$ of $0.5 \mathrm{~mol} \mathrm{dm}^{-3} \mathrm{~Pb}\left(\mathrm{CH}_{3} \mathrm{SO}_{3}\right)_{2}$ and $0.5 \mathrm{~mol} \mathrm{dm}^{-3} \mathrm{CH}_{3} \mathrm{SO}_{3} \mathrm{H}$, with $5 \mathrm{mmol} \mathrm{dm}{ }^{-3}$ HDTMA. Limited by shorting through deposit contact, only 40 cycles were achieved at $88 \%$ charge efficiency and 74\% voltage efficiency. Almost four times as many cycles are achieved here (150) averaging $73 \%$ energy efficiency, compared to the 40 cycles with $65 \%$ average energy efficiency achieved under similar conditions in the literature [4]. A further measure of performance for flow batteries can be defined as the total charge Ah applied to the system and the associated total charge efficiency for the discharge process. At the $100 \mathrm{~cm}^{2}$ or above electrode scale, the SLFB has previously achieved only $108 \mathrm{Ah}$ (current density of $30 \mathrm{~mA} \mathrm{~cm}^{-2}$ ) and $164 \mathrm{Ah}$ (constant current of $10 \mathrm{~mA} \mathrm{~cm}{ }^{-2}$ ) charge at an efficiency of $94 \%$. With the current $100 \mathrm{~cm}^{2}$ cell in a semi-divided configuration, a total charge of over $300 \mathrm{Ah}$ (using a current density varying between 20 and $30 \mathrm{~mA} \mathrm{~cm}^{-2}$ ) has been achieved. This represents a doubling of the lifetime of the lower current density and almost three times the lifetime at the higher current density.

\section{Conclusion}

- Three configurations of SLFB have been presented: conventional undivided along with the novel semidivided and fully divided configurations. Both the semi- and fully divided configurations provide enhances cycle life compared to the conventional undivided system. The addition of a separator reduces the possibility of electrode deposits bridging the interelectrode gap and forming an electrical short in the semi- and fully divided configurations. In addition, in the fully divided configuration, it is possible to utilise electrode-specific additives in the electrolyte.

- $\mathrm{Bi}^{3+}$ has shown to improve the kinetics of the $\mathrm{Pb}^{2+} /$ $\mathrm{PbO}_{2}$ reaction and hence improve cell efficiency and lifetime; however it is not suitable in an undivided or semi-divided system and must be confined in the positive half-cell's flow network as part of a fully divided system. Further work needed here. Alternatively, future work must focus on a fully divided soluble lead system with lignosulfonate in the negative half-cell and $\mathrm{Bi}^{3+}$ in the positive.

- Voltage efficiency penalty when using additives, but a better charge efficiency and so a longer cycle life, which would offset the slightly lower energy efficiencies when using additives.

- Incorporating a separator into a $100 \mathrm{~cm}^{2}$ cell using the semi-divided configuration resulted in an increased cycle life compared to similar, previously reported, cells. The cell was charged for over $300 \mathrm{Ah}$, cycling with the current densities ranging from 20 to $50 \mathrm{~mA} \mathrm{~cm}^{-2}$.

- Further work will be undertaken to characterise the semi- and fully divided configurations to assess their relative merits. The choice of configuration is likely to be determined by the electrolyte composition. If electrode-specific additives are required, the fully divided system is likely to have an advantage; however, the less complex (single-electrolyte flow system) offered by the semi-divided configuration may offer cost advantages if an electrolyte composition suitable for both electrode reactions can be formulated.

Acknowledgements The authors would like to thank the Department for Energy and Climate Change (DECC) for their financial support, through the 'Energy Storage Component Research \& Feasibility Study Scheme'.

Open Access This article is distributed under the terms of the Creative Commons Attribution 4.0 International License (http://creativeco mmons.org/licenses/by/4.0/), which permits unrestricted use, distribution, and reproduction in any medium, provided you give appropriate 
credit to the original author(s) and the source, provide a link to the Creative Commons license, and indicate if changes were made.

\section{References}

1. Hazza A, Pletcher D, Wills R (2004) A novel flow battery: a lead acid battery based on an electrolyte with soluble lead(ii) Part I. Preliminary studies. Phys Chem Chem Phys 6:1773-1778

2. Pletcher D, Zhou H, Kear G, Low CTJ, Walsh FC, Wills RGA (2008) A novel flow battery: a lead-acid battery based on an electrolyte with soluble lead(II) Part VI. Studies of the lead dioxide positive electrode. J Power Sources 180:630-634

3. Pletcher D, Wills R (2005) A novel flow battery: a lead acid battery based on an electrolyte with soluble lead(II) Part III. The influence of conditions on battery performance. J Power Sources 149:96-102

4. Hazza A, Pletcher D, Wills R (2005) A novel flow battery: a lead acid battery based on an electrolyte with soluble lead(II) Part IV. The influence of additives. J Power Sources 149:103-111

5. Krishna M, Wallis LPJ, Wills RGA, Hall D, Shah AA (2017) Measurement of key electrolyte properties for improved performance of the soluble lead flow battery. Int J Hydrogen Energy 42:18491-18498

6. Pletcher D, Wills R (2004) A novel flow battery: a lead acid battery based on an electrolyte with soluble lead(ii) Part II. Flow cell studies. Phys Chem Chem Phys 6:1779-1785

7. Pletcher D, Zhou H, Kear G, Low CTJ, Walsh FC, Wills RGA (2008) A novel flow battery: a lead-acid battery based on an electrolyte with soluble lead(II) Part V. Studies of the lead negative electrode. J Power Sources 180:621-629

8. Wills RGA, Collins J, Stratton-Campbell D, Low CTJ, Pletcher D, Walsh F (2010) Developments in the soluble lead-acid flow battery. J Appl Electrochem 40:955-965

9. Collins J, Li X, Pletcher D, Tangirala R, Stratton-Campbell D, Walsh FC et al (2010) A novel flow battery: a lead acid battery based on an electrolyte with soluble lead(II) Part IX: electrode and electrolyte conditioning with hydrogen peroxide. J Power Sources 195:2975-2978

10. Collins J, Kear G, Li X, Low CTJ, Pletcher D, Tangirala R et al (2010) A novel flow battery: a lead acid battery based on an electrolyte with soluble lead(II) Part VIII. The cycling of a $10 \mathrm{~cm} \times$ $10 \mathrm{~cm}$ flow cell. J Power Sources 195:1731-1738

11. Krishna M, Fraser EJ, Wills RGA, Walsh FC (2018) Developments in soluble lead flow batteries and remaining challenges: an illustrated review. J Energy Storage 15:69-90

12. Wallis LPJ, Wills RGA (2014) Membrane divided soluble lead battery utilising a bismuth electrolyte additive. J Power Sources 247:799-806

13. Velichenko AB, Devilliers D (2007) Electrodeposition of fluorinedoped lead dioxide. J Fluor Chem 128:269-276

14. Oury A, Kirchev A, Bultel Y (2014) Cycling of soluble lead flow cells comprising a honeycomb-shaped positive electrode. J Power Sources 264:22-29

15. Ghasemi S, Mousavi MF, Shamsipur M (2007) Electrochemical deposition of lead dioxide in the presence of polyvinylpyrrolidone: a morphological study. Electrochim Acta 53:459-467

\section{Affiliations}

\section{Krishna ${ }^{1}$ R. G. A. Wills ${ }^{1}$ (D) A. A. Shah ${ }^{2}$ - D. Hall ${ }^{3}$. J. Collins ${ }^{3}$}

1 Energy Technology Research Group, Faculty of Engineering and the Environment, University of Southampton, Highfield, Southampton SO17 1BJ, UK

2 School of Engineering, University of Warwick, Coventry CV4 7AL, UK
3 C-Tech Innovation Ltd., Capenhurst Technology Park, Chester CH1 6EH, UK 